\title{
The effect of dilution of milk proteins with non-essential amino acids ( $L$-alanine and L-glutamic acid) on nitrogen retention and biological value of the proteins in children
}

\author{
BY V. A. DANIEL, T. R. DORAISWAMY, M. SWAMINATHAN \\ AND D. RAJALAKSHMI \\ Central Food Technological Research Institute, Mysore-2a, India
}

(Received 25 November 1969-Accepted 20 fanuary 1970 )

\begin{abstract}
I. The effect of addition of a mixture of two non-essential amino acids (NEA), namely alanine and glutamic acid, to milk proteins on nitrogen retention and the biological value of the proteins was determined in a group of six girls aged ro- I I years.

2. The mean daily intakes of milk protein by the children on three diets $(I, 3$ and 5 ) were $I \cdot 4 r$, I.IO and $0.70 \mathrm{~g} / \mathrm{kg}$ body-weight. The quantities of NEA added daily to the three diets were $0.97,0.49$ and $0.97 \mathrm{~g} / \mathrm{kg}$ body-weight respectively.

3. Addition of NEA did not bring about any significant increase in $\mathbf{N}$ retention in the children. The addition of NEA to milk proteins significantly decreased the biological value of the proteins.
\end{abstract}

It is now well recognized that the biological value (Bv) of dietary proteins depends on the content, availability and balance of essential amino acids in them (Block \& Mitchell, 1946; Swaminathan, I964, 1967; Swaminathan \& Daniel, r968). The FAO/ WHO Expert Group on Protein Requirements (FAO, 1965) suggested that, after the required pattern of the essential amino acids has been specified, the percentage of the total nitrogen intake contributed by the essential amino acids must be indicated. They also stated that 'there is good reason to believe that in both human milk and egg proteins, the proportions of essential amino acids are higher than those required for older children and adults, although the physiological reason for this is not clear'. Snyderman, Holt, Dancis, Roitman, Boyer \& Balis ( 1962$)$ reported that addition of glycine or urea to a milk diet providing $\mathrm{I} \cdot \mathrm{I} \mathrm{g}$ protein $/ \mathrm{kg}$ body-weight brought about increase in $\mathrm{N}$ retention and body-weight of infants. More recently Daniel, Desai, Venkat Rao, Swaminathan \& Parpia ( 1968 ) have reported that dilution of milk proteins with a non-essential amino acid (glutamic acid) brings about a decrease in the protein efficiency ratio (PER) of the proteins in proportion to the quantity of glutamic acid added. It was considered desirable to conduct metabolic studies in growing children to confirm the findings in rats. In the present investigation, the effect of dilution of milk proteins with a mixture of two non-essential amino acids (NEA), alanine and glutamic acid, on $\mathrm{N}$ retention and $\mathrm{BV}$ of the proteins has been studied in children aged ro-I I years. 


\section{EXPERIMENTAL}

\section{Materials}

Spray-dried skim-milk powder (SMP) of good quality prepared from buffalo milk was used in this study. L-Alanine and L-glutamic acid (E. Merck) were used as the source of NEA.

\section{Subjects}

The subjects were eight girls aged IO-r I years and were residents of a boarding home in Mysore City. The ages, heights and weights of the girls are given in Table $\mathrm{x}$. All of them belonged to low-income groups of the population and were in good health.

\section{Diets}

The composition of the low-protein basal diet (7) used in this study is given in Table 2. This diet provided $2000 \mathrm{kcal}$ and about $0.74 \mathrm{~g} \mathrm{~N}$ per child per $\mathrm{d}$ derived from vegetables, maize starch and small amounts of SMP included in the diet. The children

\section{Table I. Ages, heights and weights of the children at the beginning of the test}

$\begin{array}{cccc}\begin{array}{c}\text { Girl } \\ \text { no. }\end{array} & \begin{array}{c}\text { Age } \\ \text { (years) }\end{array} & \begin{array}{c}\text { Height } \\ \text { (cm) }\end{array} & \begin{array}{c}\text { Weight } \\ \text { (kg) }\end{array} \\ \text { I } & \text { II } & 137 \cdot 8 & 29 \cdot 1 \\ 2 & \text { II } & 129 \cdot 5 & 27 \cdot 7 \\ 3 & \text { II } & 126 \cdot 4 & 21 \cdot 6 \\ 4 & \text { IO } & 123 \cdot 8 & 21 \cdot 6 \\ 5 & \text { IO } & 120 \cdot 0 & 22 \cdot 0 \\ 6 & \text { IO } & 116 \cdot 2 & 19 \cdot 8\end{array}$

received the low-protein diet in all the periods. In addition they received varying quantities of SMP or a blend of SMP and two NEA, alanine and glutamic acid, as shown in Table 2 (diets I-6). Mineral salts and vitaminized starch were mixed with the maize starch. Maize starch was made into a sweet or savoury pudding or pancake. SMP and blends of SMP with NEA were reconstituted with six times the weight of water and were consumed in three equal portions along with the low-protein diets.

\section{Feeding of children and collection of excreta}

The children were fed three times a day (in the morning, at noon and at night). The metabolism period consisted of seven periods of $12 \mathrm{~d}$ each and the diets were given in the same numerical order $\mathrm{I}-7$ for each child. The first $7 \mathrm{~d}$ on each diet were treated as a preliminary period for the children to become accustomed to the diet and the collection of urine and faeces was confined to the last $5 \mathrm{~d}$ in each period. Carmine was used as a marker for the collection of faeces. The daily excretion of creatinine in the urine of the subjects ranged from $55^{6}$ to $612 \mathrm{mg} / \mathrm{d}$. In the same subject the daily excretion of creatinine on different days of the metabolism study did not differ by more than $5 \%$, suggesting that the collection of urine was probably complete. Duplicate samples of the diets consumed by each child in the different periods were collected and dried 
at $60-65^{\circ}$ in a cabinet drier. The diets were powdered and preserved in glass-stoppered bottles for analysis. The urine and faeces were preserved by the method of Murthy, Swaminathan \& Subrahmanyan (I954).

Table 2. Mean daily intake of foodstuffs, milk protein and added non-essential amino acids (NEA) from different diets*

\begin{tabular}{|c|c|c|c|c|c|c|c|}
\hline \multirow[b]{2}{*}{ Ingredient } & \multicolumn{7}{|c|}{ Diet } \\
\hline & $\mathbf{I}$ & 2 & 3 & 4 & 5 & 6 & 7 \\
\hline Maize starch (g) & 300 & 300 & 325 & 325 & $35^{\circ}$ & 350 & 395 \\
\hline Skim-milk powder (g) & 100 & 100 & 75 & 75 & 50 & 50 & 5 \\
\hline $\begin{array}{c}\text { NEA: glutamic acid (g) } \\
\text { alanine }(\mathrm{g})\end{array}$ & - & $\begin{array}{r}14.5 \\
8.8\end{array}$ & - & $\begin{array}{l}7 \cdot 25 \\
4 \cdot 40\end{array}$ & - & $\begin{array}{l}14 \cdot 5 \\
8.8\end{array}$ & - \\
\hline \multicolumn{8}{|l|}{ Protein and NEA intake: } \\
\hline Protein from SMP (g) & $33 \cdot 8$ & $33 \cdot 8$ & $25 \cdot 4$ & $25 \cdot 4$ & $16 \cdot 9$ & 16.9 & $I \cdot 7$ \\
\hline $\begin{array}{l}\text { Protein from SMP ( } \mathrm{g} / \mathrm{kg} \\
\text { body-wt) }\end{array}$ & $\lg I \cdot 4 I$ & $\mathrm{I} \cdot 4 \mathrm{I}$ & $\mathrm{I} \cdot \mathrm{IO}$ & $1 \cdot 0$ & 0.70 & 0.70 & 0.07 \\
\hline NEA $(g)$ & - & $23 \cdot 3$ & - & II. 65 & - & 23.3 & - \\
\hline NEA (g/kg body-wt) & - & 0.97 & - & 0.49 & - & 0.97 & - \\
\hline \multicolumn{8}{|l|}{ Nitrogen: $\uparrow$} \\
\hline From milk (g) & $5 \cdot 44$ & $5 \cdot 44$ & 4.13 & 4.13 & $2 \cdot 72$ & $2 \cdot 72$ & 0.27 \\
\hline From NEA (g) & - & $2 \cdot 70$ & - & $\mathrm{I} \cdot 35$ & - & $2 \cdot 70$ & - \\
\hline $\begin{array}{l}\text { From low-protein } \\
\text { diet (basal diet) }\end{array}$ & 0.74 & 0.74 & 0.74 & 0.74 & 0.74 & 0.74 & 0.74 \\
\hline Total & $6 \cdot 18$ & $8 \cdot 88$ & $4 \cdot 87$ & $6 \cdot 22$ & 3.46 & $6 \cdot 16$ & 0.74 \\
\hline
\end{tabular}

* All the diets contained in addition $(\mathrm{g} / \mathrm{d})$ : vegetables (brinjal, beans and vegetable marrow), 160 ; onion, 25 ; tamarind fruit pulp, 5 ; crude sea-salt, 15 ; tea leaves, 6 ; cane-sugar, 48 ; groundnut oil, 40 ; coconut, fresh, 15; condiments (garlic, coriander seeds, mustard, red chillies and turmeric), 7.

$\dagger$ Calculated from the $\mathrm{N}$ content of skim-milk powder, NEA and basal low-protein diet; the values given in Table 5 were estimated on mixed diets collected during the metabolic study.

\section{Analytical methods}

The essential amino acid contents (excepting tryptophan) of the proteins of SMP and the low-protein diet used in this study were determined by microbiological methods (Barton-Wright, 1952). Tryptophan was determined by the method of Spies (1950).

Total $\mathrm{N}$ in the diets, urine and faeces was determined by the micro-Kjeldhal method. The true digestibility coefficient (DC) and BV of the proteins were calculated according to Tasker, Doraiswamy, Narayanarao, Swaminathan, Sreenivasan \& Subrahmanyan (1962).

\section{Statistical analysis}

The results were analysed by the analysis of variance method appropriate for randomized block design considering each subject as a block, and differences were tested for significance by means of Duncan's multiple range test.

\section{RESULTS}

The essential amino acid contents of SMP and blends of SMP with NEA are given in Table 3 , together with the ratios of essential amino acids to total $\mathrm{N}$ and chemical 
scores. The chemical scores were calculated according to Block \& Mitchell (I946) using the reference amino acid pattern of FAO ( 1965$)$ for egg proteins.

The mean daily milk-protein intake (Table 2) for children on diets I and 2, 3 and 4 , 5 and 6 were $1 \cdot 4 \mathrm{I}, \mathrm{I} \cdot \mathrm{ro}$ and $0 \cdot 70 \mathrm{~g}$ respectively compared with reference protein requirements of 0.72 suggested by the FAO/WHO Expert Group on Protein Requirements (FAO, 1965).

Table 3. Essential amino acids contents $(g / \mathbf{1} 6 \mathrm{~g} N)$, ratio of essential amino acids to total nitrogen $(E: T N)$ and chemical score of skim-milk powder (SMP) and blends of skim-milk powder and non-essential amino acids (NEA)

\begin{tabular}{|c|c|c|c|c|}
\hline & Diet I & Diet 2 & Diet 4 & Diet 6 \\
\hline \multicolumn{5}{|l|}{ Essential amino acids: } \\
\hline Arginine & $3 \cdot 7$ & $2 \cdot 5$ & $2 \cdot 8$ & $1 \cdot 9$ \\
\hline Histidine & $2 \cdot 7$ & $1 \cdot 8$ & $2 \cdot 0$ & $1 \cdot 4$ \\
\hline Isoleucine & $6 \cdot 5$ & $4 \cdot 3$ & $4 \cdot 9$ & $3 \cdot 3$ \\
\hline Leucine & $10 \cdot 0$ & $6 \cdot 7$ & $7 \cdot 5$ & $5 \cdot 0$ \\
\hline Lysine & $7 \cdot 9$ & $5 \cdot 3$ & $5 \cdot 9$ & $4 \cdot 0$ \\
\hline Cystine & 0.9 & 0.6 & 0.7 & 0.4 \\
\hline Methionine & $2 \cdot 5$ & $\mathbf{I} \cdot 7$ & $I \cdot 9$ & $1 \cdot 2$ \\
\hline Phenylalanine & 4.9 & $3 \cdot 3$ & 3.8 & $2 \cdot 4$ \\
\hline Threonine & 4.7 & $3^{*} I$ & $3 \cdot 5$ & $2 \cdot 3$ \\
\hline Tryptophan & $1 \cdot 4$ & $0 \cdot 9$ & $\mathbf{I} \cdot \mathbf{I}$ & $0 \cdot 7$ \\
\hline Valine & $7 \cdot 0$ & $4 \% 7$ & $5 \cdot 3$ & $3 \cdot 5$ \\
\hline Ratio, SMP: NEA nitrogen & $1: 0$ & $2: 1$ & $3: 1$ & $\mathbf{I}: \mathbf{I}$ \\
\hline Total essential amino acids $(\mathrm{g} / \mathrm{r} 6 \mathrm{~g} \mathrm{~N})$ & $52 \cdot 2$ & $34 \cdot 8$ & $39^{\circ} 0$ & $26 \cdot 1$ \\
\hline Ratio, E:TN & $3 \cdot 26$ & $2 \cdot 17$ & $2 \cdot 44$ & $x \cdot 63$ \\
\hline Chemical score (taking egg protein as Ioc & 60 & 40 & & \\
\hline
\end{tabular}

Table 4. Daily urinary and faecal excretion $(g)$ of nitrogen by the children on the low-protein diet 7

$\begin{array}{ccc}\text { Girl no. } & \text { Urinary } & \text { Faecal } \\ \text { I } & \mathrm{I} \cdot 28 & 0.68 \\ 2 & 0.94 & \mathrm{I} \cdot 02 \\ 3 & \mathrm{I} \cdot 44 & 0.74 \\ 4 & \mathrm{I} \cdot 07 & 0.84 \\ 5 & \mathrm{I} \cdot \mathrm{I} 8 & 0.8 \mathrm{I} \\ 6 & 0.93 & 0.83 \\ \text { Mean value with its } & \mathrm{I} \cdot 14 \pm 0.08 & 0.82 \pm 0.05 \\ \text { standard error }(5 \mathrm{df}) & & \end{array}$

The results for $\mathrm{N}$ balance are summarized in Table 5. The mean daily $\mathrm{N}$ intakes on diets $\mathrm{x}, 4$ and 6 were nearly the same, ranging from $6 \cdot 12$ to $6.3 \mathrm{I} \mathrm{g}$, while the intakes on diets 2,3 and 5 were $8 \cdot 44,5 \cdot 12$ and $3.62 \mathrm{~g}$ respectively. The mean daily $\mathrm{N}$ retention on diet $\mathrm{I}$, containing $33.8 \mathrm{~g}$ milk protein, was $\mathrm{I} \cdot 44 \mathrm{~g}$. Addition of $23.3 \mathrm{~g}$ NEA (diet 2) brought about only a slight increase in the $\mathrm{N}$ retention, to $\mathrm{r} \cdot 62 \mathrm{~g}$. When the milkprotein intake was reduced to $25^{\circ} 4 \mathrm{~g}$ (diet 3 ) the $\mathrm{N}$ retention was only $\mathrm{r} \cdot \mathrm{\circ}$ g. When supplemented with $\mathrm{I}_{\mathrm{r}} \cdot 65 \mathrm{~g} \mathrm{NEA}$ (diet 4 ) the $\mathrm{N}$ retention increased slightly to $\mathrm{r} \cdot 20 \mathrm{~g}$. When the milk-protein intake was restricted to only $16.9 \mathrm{~g}$ daily (diet 5 ), the mean $\mathrm{N}$ retention was reduced to $0.3 \mathrm{I} \mathrm{g}$. When supplemented with $23.3 \mathrm{~g} \mathrm{NEA}$, the $\mathrm{N}$ retention increased slightly to $0.37 \mathrm{~g}$. 
Vol. 24

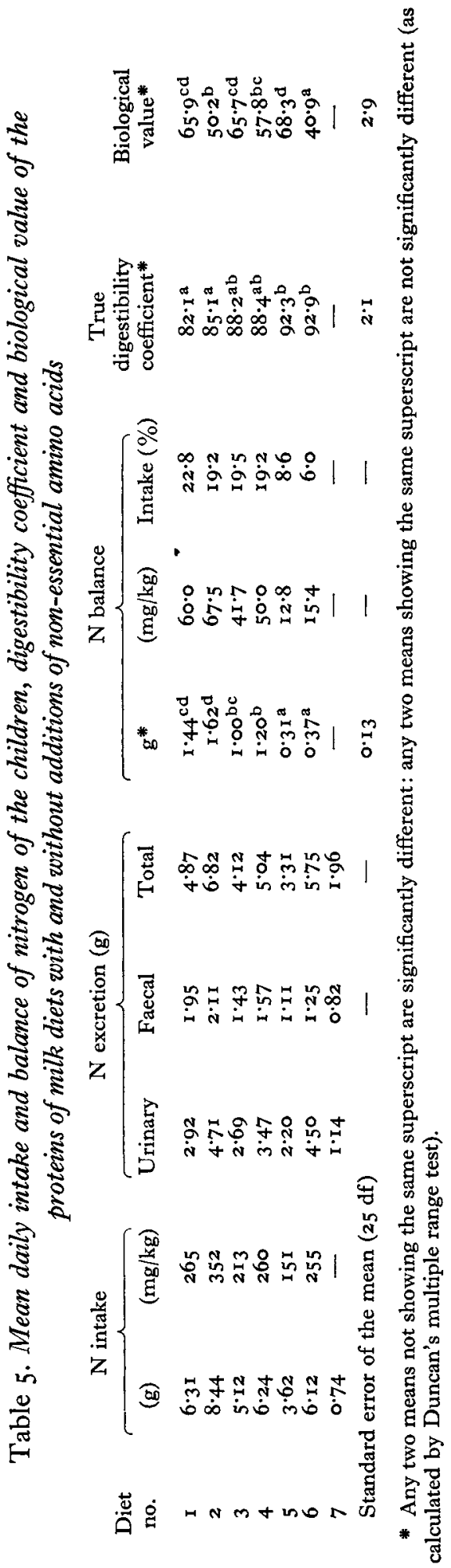


The mean DC ranged from $82 \cdot \mathrm{I}$ on a protein intake of $33 \cdot 8 \mathrm{~g}$ to $92 \cdot 3$ on a protein intake of $\mathrm{I} 6 \cdot 9 \mathrm{~g}$. The $\mathrm{BV}$ of milk protein in diets $\mathrm{I}, 3$ and 5 ranged from $65 \cdot 7$ to $68 \cdot 3$. Addition of NEA brought about a highly significant decrease in Bv. This was to be expected, as dilution with NEA brings about a reduction in the effective concentration of essential amino acids and also in the chemical scores of the blends. For example, (I) dilution of $33.8 \mathrm{~g}$ milk protein with $23.39 \mathrm{~g}$ NEA brought about a reduction in BV from 65.7 to $50^{\circ} \cdot 2 \mathrm{~g}$; (2) dilution of $25^{\circ} \cdot 4 \mathrm{~g}$ milk protein with $11.65 \mathrm{~g}$ NEA brought about a reduction in Bv from $65^{.9}$ to $57^{\circ} 6$ and (3) dilution of $16.9 \mathrm{~g}$ milk protein with $23.3 \mathrm{~g}$ NEA brought about a reduction in the Bv from 68.3 to $40^{\circ} \cdot 9$.

\section{DISCUSSION}

In the present study each child received the diets in the same order. Hence the design will not detect any 'trend with time' that could obscure the true effect of dietary treatments. Since the experimental periods were of short duration, the design adopted was not likely to affect the interpretation of results. A similar procedure was followed by Scrimshaw, Bressani, Behar \& Viteri (1958) in their studies on the effect of amino acid supplementation of a maize diet on $\mathrm{N}$ retention in children. Even though $\mathrm{N}$ metabolic studies are open to systematic errors (Wallace, 1959), they can, nevertheless, yield reliable results when comparative studies are made under the same conditions (Scrimshaw et al. 1958). For example, in the present study, the daily $\mathrm{N}$ intakes on diets I, 3 and 5 were $6.31,5.12$ and $3.62 \mathrm{~g}$ and the corresponding $\mathrm{N}$ retentions were $\mathrm{I} \cdot 44$, $\mathrm{r} \cdot 0$ and $0.3 \mathrm{I} \mathrm{g}$, indicating that the differences in $\mathrm{N}$ intake are promptly reflected in $\mathrm{N}$ retention.

The results obtained in the present study have shown that addition of NEA to milk proteins did not bring about a significant increase in $\mathrm{N}$ retention in children. These results are not in agreement with those reported by Snyderman et al. (1962) on infants and by Scrimshaw, Young, Haung, Thanangkul \& Cholakos (1969) in young adults. Snyderman et al. (1962) reported that a daily addition of non-essential nitrogen in the form of urea and glycine to the diet of infants receiving $\mathrm{I} \cdot \mathrm{I} \mathrm{g}$ milk protein $/ \mathrm{kg}$ bodyweight brought about a significant increase in $\mathrm{N}$ retention. Since the NPU $(\mathrm{DC} \times \mathrm{BV} \div 100)$ of milk proteins obtained in this study varied from 54 to 63 , the net available protein from diets I, 3 and 5 would be about $0.76,0.61$ and $0.45 \mathrm{~g} / \mathrm{kg}$ body-weight. It is obvious that diet I provides just adequate amounts of protein, while diets 3 and 5 do not, when compared with the reference protein requirement of $0.72 \mathrm{~g}$ suggested by FAO/WHO Committee (FAO, 1965). The mean daily $\mathrm{N}$ retentions on diets $\mathrm{I}, 3$ and 5 were $\mathrm{I} \cdot 44, \mathrm{I} \cdot \mathrm{O}$ and $\mathrm{O} \cdot 3 \mathrm{I} \mathrm{g}$ and these values did not increase to a significant extent when NEA were added to the diets.

Scrimshaw et al. (I969) found that replacement of $25 \%$ of milk protein with NEA did not change urinary $\mathrm{N}$ excretion in young adults. In the present study, replacement of $25 \%$ of milk protein by NEA increased the mean daily urinary $\mathrm{N}$ excretion from 2.92 to $3.47 \mathrm{~g}$ (diets $\mathrm{I}, 4$ ). The results clearly indicate that milk proteins contain adequate amounts of NEA for the maximum utilization of essential amino acids as indicated by the values found for the BV of proteins; the BV of milk proteins ranged 
from $65 \cdot 6$ to $68 \cdot 2$. Addition of NEA to milk proteins brought about a marked decrease in BV depending on the quantity of NEA added.

We are thankful to the National Institutes of Health, US Public Health Service, for a grant-in-aid from PL 480 funds.

\section{REFERENCES}

Barton-Wright, E. C. (1952). Microbiological Assay of the Vitamin B Complex and Amino Acids. London: Issac Pitman and Sons Ltd.

Block, R. J. \& Mitchell, H. H. (1946). Nutr. Abstr. Rev. 16, 249.

Daniel, V. A., Desai, B. L. M., Venkat Rao, S., Swaminathan, M. \& Parpia, H. A. B. (I968). F. Fd. Sci. 33, 432 .

FAO (1965). F.A.O. Nutr. Mtg Rep. Ser. no. 37.

Murthy, H. B. N., Swaminathan, M. \& Subrahmanyan, V. (1954). Br. F. Nutr. 8, I I.

Scrimshaw, N. S., Bressani, R., Behar, M. \& Viteri, F. (1958). F. Nutr. 66, 485.

Scrimshaw, N. S., Young, V. R., Haung, P. C., Thanangkul, O. \& Cholakos, B. V. (1969). F. Nutr.98, 9. Snyderman, S. E., Holt, L. E., Dancis, J., Roitman, E., Boyer, A. \& Balis, M. E. (I962). F. Nutr. $78,57$. Spies, J. R. (1950). Analyt. Chem. 22, 1447.

Swaminathan, M. (1964). F. Nutr. Dietet. I, 59.

Swaminathan, M. (1967). In Newer Methods of Nutritional Biochemistry Vol. 3, p. 197 [A. A. Albanese, editor]. New York: Academic Press, Inc.

Swaminathan, M. \& Daniel, V. A. (1968). F. Nutr. Dietet. 5, I64.

Tasker, P. K., Doraiswamy, T. R., Narayanarao, M., Swaminathan, M., Sreenivasan, A. \& Subrahmanyan, V. (1962). Br. F. Nutr. 16, 36r.

Wallace, W. M. (1959). Fedn Proc. Fedn Am. Socs exp. Biol. 18, 1125. 